\title{
Board monitoring and capital structure dynamics: evidence from bank-based economies
}

\author{
Ernest Ezeani ${ }^{1}$ (D) $\cdot$ Rami Salem $^{2} \cdot$ Frank Kwabi $^{3} \cdot$ Khalid Boutaine $^{2} \cdot$ Bilal $^{4}(\mathbb{D}$. \\ Bushra Komal ${ }^{5}$
}

Accepted: 24 June 2021 / Published online: 4 July 2021

(c) The Author(s) 2021

\begin{abstract}
We examine the impact of board characteristics on the speed of adjustment and the capital structure dynamics of firms in bank-based economies. Using 3927 firm-year observations over a 10-year (2009-2019), we find that board characteristic influences firms' speed of adjustment in a bank-based (stakeholder-oriented) system. We also find some evidence that board characteristics have varying impacts on the capital structure of Japanese, French and German firms. We conclude that firms' capital structure reflects the corporate governance environment they operate. Our results are robust to accounting for endogeneity and alternative leverage measure.
\end{abstract}

Keywords Capital Structure $\cdot$ Capital Structure $\cdot$ Board characteristics $\cdot$ Speed of adjustment $\cdot$ Bank-based

JEL Classifications G32

Ernest Ezeani

E.Ezeani@mmu.ac.uk

Rami Salem

riasalem1@uclan.ac.uk

Frank Kwabi

frank.kwabi@dmu.ac.uk

Khalid Boutaine

kboutaine@uclan.ac.uk

Bilal

bilal@hbue.edu.cn

Bushra Komal

bushrakomal@hotmail.com

1 Manchester Metropolitan University, Manchester M156BH, UK

2 University of Central Lancashire, Preston PR21HE, UK

3 De Montfort University, Leicester LE19BH, UK

4 Hubei University of Economics, Wuhan, China

5 University of International Business and Economics, Beijing, China 


\section{Introduction}

Prior studies have shown the importance of agency relationships on firms' financing decisions. These studies postulate that corporate governance characteristics are important determinants of firms' capital structure (Becker-Blease and Irani 2008; Kieschnick and Moussawi 2018; Kim et al. 2007; Liao et al. 2015; Morellec et al. 2012). One key channel through which corporate governance influences firms' capital structure in a shareholderoriented CG environment is by adjusting leverage to the level desired by the firm's shareholders (Jensen and Meckling 1976). In line with the agency theory of free cash flow, the board is likely to support more debt to reduce cash diversion and free cash flow available to firms' managers. Its role is to ensure that shareholders decide what is considered an optimal debt level. Thus, leverage is an essential instrument of control in (market-based) shareholder-oriented CG environment such as in the UK and US.

The question that is likely to arise is whether the corporate board influences firms' financing decisions in the same way in bank-based economies. This issue is vital given the distinction between bank-based and market-based economies in finance literature (Bats and Houben 2020; Beck and Levine 2002; Chakraborty and Ray 2006; Levine 2002). Studies have also shown that formal institutions and national contexts have implications for firms' financing decisions (Johnson et al. 2010), which implies that capital structure may differ even within bank-based system.

This study, therefore, examines the impact of board characteristics on the capital structure dynamics of Japanese, German and French firms, which are classified as bank-based economies with a different (stakeholder-oriented) corporate governance (CG) approach. Our research is interesting since, on the one hand, these countries have similar financial orientations and corporate governance systems (La Porta et al. 2000). On the other hand, they have remarkable differences in their corporate governance environment despite the ongoing convergence efforts (O'Sullivan 2003). These three countries provide the desired setting to examine whether board monitoring has an impact on firms' capital structure.

Our motivation for undertaking this study is as follows: First, empirical findings in countries classified as bank-based are not keeping up with the theoretical development in capital structure research. Notably, previous capital structure studies have ignored the impact of corporate governance on firms' leverage in market-based economies (Kieschnick and Moussawi 2018; Morellec et al. 2012). These studies assume that the lessons learned from the market-based (shareholder-oriented) environment are generalizable to the stakeholderoriented setting. In the Anglo-Saxon literature, the widely held view is that firms' capital structure decisions should reflect shareholders' interest (Hackbarth 2008; Harris and Raviv 1991; Himmelberg and Tsyplakov 2020; Nguyen et al. 2020). Consequently, the prevailing CG model is designed to advance the interest of firms' shareholder (Kim et al. 2007; Liao et al. 2015; Morellec et al. 2012; Nguyen et al. 2020) by limiting managerial preferences through monitoring duties of outside directors (Endo 2020). However, unlike Anglo-Saxon (market-based) economies, Japan, Germany, and France operate a stakeholder CG system that deviates from the Anglo-Saxon corporate governance model (Hopt and Leyens 2004; Kim et al. 2007; Levine 2002; Schmidt and Tyrell 1997).

Secondly, despite the similarities between Japan, Germany, and France as bank-based economies, studies suggest that corporate governance varies across these countries (Dore 2005; Jackson and Moerke 2005; Kim et al. 2007). For instance, the legal dimension of the German co-determination principle is not comparable with French firms' involvement of employees using work councils. It, therefore, contradicts the informal 
employee participation in Japan. Furthermore, Germany's mandatory two-tier board arrangement (Management and supervisory board) sharply contrasts Japan's unitary model or a voluntary board arrangement in France. Studies also show that Japan's corporate governance model is less rigid than the model employed in Germany and France (Endo 2020; Jackson and Moerke 2005). Jackson and Moerke (2005) suggest that the Japanese CG is a community model while Germany has a constitutional model.

Finally, most studies adopted an agency approach in (Anglo-Saxon) market-based economies (Barnea et al. 1981; Hackbarth 2008; Harris and Raviv 1991; Harvey et al. 2004; Leland and Toft 1996; Mauer and Sarkar 2005). This one-sided approach has led to the popularity of the shareholder-oriented CG model as a baseline for comparative evaluation of firms' capital structure decisions (Kieschnick and Moussawi 2018; Morellec et al. 2012). The implication is that the impact of board monitoring on firms' capital structure in the non-English-speaking world is still unclear (Dore 2005).

Therefore, using panel data of 3927 firm-year observation from 2009 to 2019, we examine the impact of board characteristics on Japanese, German, and French firms' capital structure dynamics. We show that the impact of board characteristics on firms' capital structure varies across bank-based economies. Board gender diversity is inversely related to market leverage in France and Germany. However, we found no relationship for Japanese firms. Similarly, outside directors and board meetings are negatively associated with market leverage in Germany but show a positive relationship in Japan. Board size is inversely related to our leverage proxies in all countries. We employed book leverage as an alternative proxy of firms' capital structure and found similar results. We also re-estimated our study equation by comparing the impact of board characteristics on the market leverage across EU countries (Germany and France) and Japan. We found that board characteristics are inversely related to market leverage in EU countries (Germany and France). However, in line with our main results, outside director and board meetings are positively associated with leverage among Japanese firms. We also confirm that board gender diversity is not a capital structure determinant in Japan. Our findings are neither influence by zero-debt firms nor mechanical mean reversion (e.g., Chang and Dasgupta 2009). Using Wilcoxon and T-test, we confirm a significant difference between Japanese, German, and French firms.

Our key contributions are as follows. Previous evidence on the impact of corporate governance on capital structure focuses on firms in market-based economies, especially the US (Kieschnick and Moussawi 2018; Liao et al. 2015; Morellec et al. 2012). We examine the impact of board monitoring on firms' capital structure in typical bank-based economies and found that board monitoring has varying effects on the capital structure of Japanese, German and French firms. Secondly, we reported higher SOA among Japanese, German and French firms when CG variables are included in the regression and lower SOA after excluding board variables. Our result shows that the variation in corporate governance and institutional environment affects firms' adjustment behaviour regardless of the similarity of the financial system. Thirdly, we find higher SOA among German firms when compared to Japanese and French firms, implying that the strict separation between management and supervisory board is likely to influence lenders' assessment of the firm.

We structure our paper as follows: In Sect. 2, we review related literature on the impact of the board on capital structure decision. Section 3 discusses the study's methodology. In Sect. 4, we present our main results and additional tests. In Sect. 5, we conclude and discuss the policy implication of our study. 


\section{Related literature}

\subsection{Institutional background}

Bank-based economies such as Japan, France, and Germany have a unique corporate governance environment that is distinguishable from the model used in capital market economies (Dore 2005; Jackson and Moerke 2005; Köke 2004). The adoption of a stakeholder approach to corporate governance in these economies ensures that the interest of all stakeholders is protected (Feils et al. 2018). Unlike in the shareholder-oriented CG model, where an arms-length relationship is assumed between firms and their lenders, banks play an active role in firms' financing and managing agency conflict. In addition to lenders' involvement, firms in a stakeholder-oriented governance environment are required to involve their employees in the management process, thereby forming a stable coalition with various stakeholders (Fauver and Fuerst 2006; Feils et al. 2018; Jackson and Moerke 2005). Although these countries have a similar corporate governance model, they have some significant variations in their CG approach. However, unlike Japanese firms where a unitary board system operates, firms in Germany are obliged to adopt a two-tier board system. In contrast, French firms are allowed to choose either a unitary model or a two-tier system.

Japanese firms have embedded stakeholder-friendly behaviour in their corporate governance system (Aoki 2010; Endo 2020; Witt and Redding 2012). The main characteristics of a Japanese stakeholder-driven corporate governance are the unitary board system (Jackson and Moerke 2005), the dominance of insiders on the corporate board, and a limited number of outsiders on the corporate board (Endo 2020). Unlike in the German system, where the board is expected to compensate for lack of market control (Köke 2004; Tran 2014), the Japanese corporate governance system does not emphasize monitoring. Outside directors of Japanese firms are expected to bring their expertise and connections to the firms they serve. The idea is to serve their community through the service they render to their firms (Witt and Redding 2012).

Germany is a prototype of a bank-based system (Köke 2004) with a two-tier board system comprising of a management board and supervisory board (Cromme 2005; Edwards and Nibler 2000; Fauver and Fuerst 2006; Hopt and Leyens 2004; Jackson and Moerke 2005; Kim et al. 2007; Tran 2014). The management board oversees the operational activities of the firms while the supervisory board monitors the activities of the management with an additional advisory role and co-decision making (Cromme 2005; Tran 2014). The supervisory board members include employees', bank, and shareholders' representatives, thereby ensuring non-market control. Employees' representation is legally guaranteed through the co-determination framework (Edwards and Nibler 2000). The corporate governance system allows outsiders to represent various stakeholders such as large block holders, banks and employees. (Franks and Mayer 1998; Köke 2004). Closset and Urban (2019) argue that large creditors' power within the German corporate governance system substitutes non-market control.

However, unlike Germany and Japan, French firms operate primarily in a familybased financial system (Johnson et al. 2010). They are free to adopt either a unitary board system (one-tier) or a two-tier board system. Traditionally, collectivism is at the centre of France's corporate governance environment. Through work council, firms involve their employees in management (Antal and Sobczak 2007) to ensure that their 
voices are heard. Employee representation is embedded in the 1982 law that obliges firms to consult with their employees before embarking on any significant restructuring.

Although these countries are all classified as bank-based systems, they have a unique corporate governance environment. Jackson and Moerke (2005) argue that their similarity lies in their contrast with the Anglo-Saxon model. For instance, the German co-determination principle is legally embedded since giving employees a voice is a political decision deemed to be in the interest of the German public. Similarly, the two-tier board is legally enforced as a deliberate intervention (promotion of adequate checks and balances) in the management of firms. This legal dimension of the German board system is similar to that of France, whereby firms are mandated to involve employees through work councils. However, it sharply contrasts the Japanese unitary board system where management and monitoring are not separated. Unlike in Germany, Japan has no clear legal distinction between Internal and external board members. Employees' participation in Japanese firms is achieved through an informal arrangement (Jackson and Moerke 2005). Additionally, Japanese, German and French firms have incrementally reformed their corporate governance since the mid-1990 through different legislative measures. These reforms are likely to make the parallels between them more striking.

\subsection{Board characteristics and speed of leverage adjustment}

The dynamic trade-off theory argues that firms have target leverage adjusted by balancing its benefits and costs (Drobetz and Wanzenried 2006; Elsas and Florysiak 2011; Huang and Ritter 2009; Leary and Roberts 2005; Wanzenried 2006). Although Hovakimian et al. (2001) suggest a uniform adjustment speed, other studies found various determinants of speed of adjustment (Cao and Cui 2021; Dang et al. 2014; De Miguel and Pindado 2001; Drobetz and Wanzenried 2006; Komera and Lukose 2016). For instance, De Miguel and Pindado (2001), Drobetz and Wanzenried (2006) and Dang et al. (2014) show that adjustment to target leverage is not complete and is mainly driven by firm-level factors. Öztekin and Flannery (2012) and Cook and Tang (2010) documented the impact of institutional and macro-economic factors. Other studies show the relevance of cash flows (Faulkender et al. 2012), deviation from the target (Zhou et al. 2016), trade credit (Cao and Cui 2021) and debt covenant (Devos et al. 2017). Due to contradictory evidence Graham and Leary (2011) questions whether the dynamic trade-off model is sufficient to explain a firm's SOA.

Unlike the dynamic trade-off model, the pecking order theory suggests that if a firm prefers internally generated funds, its adjustment behaviour is likely to be determined by whether it has surplus funds or deficits. In line with the dynamic pecking order theory, a firm with a surplus fund is expected to conserve its borrowing capacity if its cost of equity is high, thereby resulting in asymmetry in adjustment behaviour.

Although few studies have shown the impact of corporate governance on the speed of adjustment (Kieschnick and Moussawi 2018; Liao et al. 2015; Morellec et al. 2012), these studies are conducted using data from market-based (shareholder-oriented) economies, especially the US and UK. Due to the uniqueness of their corporate governance environment and financial orientation, their finding is likely to have little implication for firms in bank-based economies with different agency logic. Unlike in bank-based economies, the widely held view in the Anglo-Saxon literature (Market-based economies) is that firms' capital structure decision should reflect shareholders' interest (Hackbarth 2008; Harris and Raviv 1991; Himmelberg and Tsyplakov 2020; Nguyen et al. 2020). 
However, bank-based economies have a stakeholder approach to corporate governance and firms enjoy a closer relationship with their creditors. The implication of this more intimate relationship is the likelihood of influencing the perception of lenders through monitoring by different stakeholder groups, resulting in a decrease in firms' cost of debt and a speedier adjustment. Studies show that dual board structure in Germany increases boards' monitoring role (Jackson and Moerke 2005; Johnson et al. 2010; Köke 2004) and mitigates agency conflict (Edwards and Nibler 2000; Fauver and Fuerst 2006). Furthermore, the strict separation between management and supervisory board (contradicts the unitary board system in Japan and voluntary arrangement in France) is likely to result in a speedier adjustment for German firms when compared to French and Japanese firms. Following the above discussions, we test the following hypothesis:

$H_{1}$ SOA will be higher for German firms compared to French and Japanese firms.

\subsection{Board characteristics and capital structure}

\subsubsection{Board gender diversity}

A board is assumed to be gender diverse if at least one female director is a board member (Adams and Ferreira 2009). Prior literature suggests that board gender diversity impacts the quality of its discussion and influences its monitoring ability (Campbell and Mínguez-Vera 2008; Gul et al. 2011; Kao et al. 2020; Komal et al. 2021). Female board members bring different perspectives to the board (Frye and Pham 2018; Reguera-Alvarado et al. 2017; Robinson and Dechant 1997) since they are not part of the 'old boys' club (Adams and Ferreira 2009). Other studies found that women have less appetite for risky decisions (Adusei and Obeng 2019; Faccio et al. 2016; Palvia et al. 2015). This risk-aversion makes it unlikely for a female board member to consider any financing option that bears significant risk, especially default risk. Given women's aversion to risk, firms leverage is likely to be below the level desired by firms' managers if significant proportion are women.

France is one of the countries with a relatively high representation of women on the corporate board. Following the Copé-Zimmermann law in 2011, listed firms are mandated to ensure a $40 \%$ gender quota in corporate boards. Similarly, German firms have significantly increased their gender quota on the board of directors since the country amended the Corporate Governance Code of (2010) by introducing a mandatory quota of $30 \%$ for all listed German firms. On the other hand, Japan has one of the lowest board gender quotas among all developed countries. Endo (2020) described the Japanese board as 'old-boy networks' due to the low level of female representation in the Japanese board. For instance, in 2016, the percentage of female directors on the Japanese board is only 3.4. Due to the increasing representation of women on the board on the supervisory board of German firms, we expect a negative relationship between board gender diversity and leverage in Germany and France and no relationship for Japanese firms. Following the above discussions, we test the following hypothesis:

$\mathrm{H}_{2}$ Board gender diversity has a negative relationship with leverage in German and French firms and no relationship in Japanese firms. 


\subsubsection{Outside directors}

The role of outside directors varies across various corporate governance environment. In a shareholder-oriented CG setting, the independence of outside directors ensures that managers' interest is aligned with that of shareholders (Uribe-Bohorquez et al. 2018). The Anglo-Saxon literature defines an independent board as one that is dominated by outsiders (Coles et al. 2008; Ferreira et al. 2018; Kim et al. 2007), who are excluded from day-to-day operation (De Villiers et al. 2011).

In bank-based economies, outside directors are not required to be independent (Endo 2020; Kim et al. 2007) and are selected from various stakeholder group. However, their responsibilities vary even within a stakeholder-oriented governance arrangement. Unlike France and Japan, the German supervisory board, for instance, comprises firms' creditors and employees. Creditors perform additional monitoring functions (Cromme 2005; Edwards and Nibler 2000; Franks and Mayer 1998; Hopt and Leyens 2004; Jackson and Moerke 2005; Tran 2014), thereby helping to mitigate agency conflict (Edwards and Nibler 2000; Fauver and Fuerst 2006; Köke 2004). This direct monitoring is likely to reduce the supposed arms-length relationship between firms and their lenders, resulting in stricter lending terms. In France, employees are indirectly involved in monitoring through the work council (Antal and Sobczak 2007). In Japan, outside directors are appointed to contribute to the firm through their skills and external resources (Endo 2020; Miwa and Ramseyer 2005) and have less monitoring role. They are expected to act as boundary spanners and to bring important business links and valuable expertise to the firm. Firms are likely to use their expertise during debt negotiation(Miwa and Ramseyer 2005). Following the above discussions, we test the following hypothesis:

$\mathbf{H}_{3}$ Outside director has a negative relationship with leverage in German and French firms and a positive relationship in Japanese firms.

\subsubsection{Board size}

Board size is another critical CG mechanism that mitigates agency conflict and affects its ability to discharge its duties effectively (Platt and Platt 2012; Upadhyay et al. 2014). Studies have shown that board size influences its activities (Cheng 2008; Conyon and Peck 1998; Hermalin and Weisbach 1988; Jensen 1993). Cheng (2008) argued that a larger board is unlikely to take drastic decisions since their decision-making processes involve more compromises. Similarly, Coles et al. (2008) argue that a larger board is likely to offer quality advice. On the other hand, Jensen (1993) suggests that a large board may lead to a coordination problem that outweighs the benefits of engaging more expert on the board. Jensen (1993) argue that a board that includes more than seven or eight members is likely to be controlled by the CEO due to its coordination issues. Other studies document empirical evidence in support of the effectivenee of smaller board (Cheng et al. 2008; Wang 2012; Yermack 1996). Since the board of German, French and Japanese firms are relatively large and include a significant level of representation from the employees, we expect a negative relationship between board size and leverage. Following the above discussions, we test the following hypothesis: 
$\mathbf{H}_{4}$ Board size has a negative relationship with leverage in German, French and Japanese firms.

\subsubsection{Board meeting}

Meeting frequency is an important monitoring mechanism (Adams and Ferreira 2009; Hahn and Lasfer 2016; Ji et al. 2020) and is used to proxy boards' responsibilities (Linck et al. 2008). Agency theory suggests that board meeting may help to align the interest of managers with those of shareholders. Although Vafeas (1999) suggest that meeting frequency does not advance the interest of shareholders, Brick and Chidambaran (2010) found that frequent meetings are beneficial and enable board members to monitor management effectively. Lorca et al. (2011) found that board meetings lower lending cost by influencing lenders' risk assessment.

In Germany and Japan, board members are mandated to meet at least four times a year. On the contrary, Viénot (1999) only recommends that the board of French firms should meet whenever it is necessary. Unlike in French firms, the frequent meeting of German and Japanese boards signals a higher level of monitoring and is likely to influence lenders' assessment positively. Following the above discussions, we test the following hypothesis:

$\mathbf{H}_{3}$ Board meeting has a positive relationship with leverage in German and Japanese firms and a negative relationship in French firms.

\section{Data and methods}

Our study sample is selected from two major European bank-based economies (France and Germany) and Japanese firms from 2009 to 2019. Using recent observation helps to account for recent changes in the corporate governance of these firms in our sample. The German firms used in this study are from SDAX, MDAX and DAX indexes, which consist of the German larges firms. We collected data from the SBF 120 and Nikkei 225 index for French and Japanese firms, respectively. We excluded utility, financial and mining firms since these firms have specific regulation which is likely to affect their capital structure. To ensure the robustness of our findings, we excluded observations with missing values. We collected our firm-level data from the Datastream and Nikkei Economic and Electronic Databank System. Our institutional characteristic variables are constructed using data from the world bank index. Our final sample consists of 2266, 759 and 902 firm-year observation for Japanese, French and German firms, respectively, which implies that we have a total firm-year observation of 3927.

\subsection{Measurement of dependent and independent variables}

Following previous Kieschnick and Moussawi (2018), we measure our independent variable as follows

$$
M K L e v_{i t}=\frac{D_{i t}}{D_{i t}+S_{i t} P_{i t}}
$$


where $D_{i t}$ is the firm's (i) financial debt at time t. $S_{i t}$ represents a firm's outstanding ordinary at time t. $P_{i t}$ denotes price per share of each firm (i) at time t.

We measure book leverage as follows,

$$
B K \operatorname{Lev}_{i t}=\frac{T D}{T A}
$$

where TD represents the total debt of a firm and TA means total assets.

Our independent variables are board characteristics such as board gender diversity (BGD), board size (BZ), Outside director (ODR) and board meeting(BM). We considered these board variables since they are the most relevant governance characteristics for effective monitoring and are likely to influence firms' adjustment behaviour. We measure BGD as the number of female directors on both executive and supervisory board; ODR is the percentage of non-executive directors on the board. BSZ is calculated as the total number of directors on the board, and BM represents the number of the board's annual meetings.

\subsection{Control variable}

We isolated the impact of firm and institutional characteristics. Regarding firm characteristics, we controlled for profitability, asset tangibility, firm size, MBV, liquidity and tax since firm-level factors are considered key determinants of capital structure and adjustment behaviour (Antoniou et al. 2008; Byoun 2008; Dang et al. 2012; De Miguel and Pindado 2001; Ozkan 2001; Wanzenried 2006). Dang et al. (2014) suggest that the variation in firmlevel factors results in differentials' adjustment cost. For instance, prior studies show that profitable firms are less likely to use debt, especially when they have internally generated funds (Frank and Goyal 2003; Shyam-Sunder and Myers 1999). Firms with tangible assets are more likely to have a higher debt ratio since the tangibility of asset is shown to mitigate firms risk of default and moral hazard problem (Rampini and Viswanathan 2013; Titman and Wessels 1988). The asset in place also mitigates adverse selection cost, resulting in a higher leverage ratio (Frank and Goyal 2009). Firm size is an inverse proxy of default risk (Rajan and Zingales 1995), implying the likelihood of obtaining less costly external debt finance. According to the pecking order theory, firms with growth opportunity (MBV) increase debt issuance, since their retained earnings are unlikely to cover their financing needs. Lipson and Mortal (2009) found that liquid firms have less need for debt finance. Öztekin (2015) suggest that optimal leverage depends on the value of a firm's tax shield.

Following Öztekin and Flannery (2012) and Wanzenried (2006), we isolate the impact of institutional factors such as stock market development (STKDEV), Growth in Gross Domestic Product (GDP_GR) and Inflation (INF). Stock market development is essential for firms' financing decision since it influences the cost of capital, affects the power of lenders such as banks and determines how agency problem is managed (Wanzenried 2006). Regarding inflation, Demirgüç-Kunt and Maksimovic (1999) argue that it increases the contracting cost of firms and their investors, while (Mills 1996) highlights the negative impact of inflation on the discount rate. Isolating the effects of these variables is relevant since firms' ability to obtain external financing depends on their credibility to investors (Wanzenried 2006). We discussed the measurement of dependent, independent and control variables in Appendix Table 9.

We employed a partial adjustment model 


$$
L e v_{i j, t}-\operatorname{Lev}_{i j, t-1}=\lambda_{j}\left(L e v_{i j, t}^{*}-\operatorname{Lev}_{i j, t-1}\right)+\delta_{i j, t}
$$

where $L e v_{i j, t}^{*}$ is the individual firms' optimal leverage ratio in year $t$ and country $j$. We allowed firms optimal leverage to vary over time and captured the SOA using $\lambda_{j}$, which expected to be between zero and $1(1>\lambda>0)$. $\lambda$ can only be 1 when optimal adjustment is made. In line with previous studies, we modelled optimal leverage $\left(L E V^{*}\right)$ is a function of the board, institutional characteristics and firm characteristics (Dang et al. 2014; Kieschnick and Moussawi 2018; Öztekin 2015). Consistent with Öztekin and Flannery (2012), we included firm fixed effects to control for the unobserved heterogeneity.

$$
\operatorname{Lev}_{i j, t}^{*}=\beta_{j} X_{i j, t-1}+F_{i j},
$$

where $F_{i j}$, and $\beta_{j}$ are coefficient vectors. $X_{i j, t-1}$ represents board characteristics, firm-level factors and institutional characteristics that are expected to influence firms' optimal leverage. Substituting our third equation (Eq. 4) into the partial adjustment model (Eq. 3), we achieved the following estimable equation

$$
\operatorname{Lev}_{i j, t}=\left(\lambda_{j} \beta_{j}\right) X_{i j, t-1}+\left(1-\lambda_{j}\right)+L e v_{i j, t}+\lambda_{j} F_{i j}+\delta_{i j, t}
$$

Unlike previous capital structure studies that applied a static framework (Rajan and Zingales 1995; Titman and Wessels 1988), we employed a dynamic capital structure model (GMM) to explain variation in firms' optimal leverage ratio. The system GMM uses an additional instrument, the orthogonal conditions between the disturbances and the lagged dependent variables in its estimation (Arellano and Bond 1991). Hansen (1982) argues that GMM's efficiency lies in its exploitation of all linear moment restrictions. We employ a two-step GMM which uses the orthogonal conditions on the variance-covariance matrix to control error correlation and heteroskedasticity (Blundell and Bond 1998). We employed the Sargan test of overidentifying restrictions for serial correlation checks. The secondorder autocorrelation is controlled using a test popularised by Arellano and Bond (1991).

\section{Results and discussion}

\subsection{Descriptive statistics}

In Table 1, we present the summary statistics of the board, firm-level and institutional variables used in this study. Our result shows that the average book leverage of French firms is $24.6 \%$ and is higher than those of German firms (20\%) and Japanese firms (18.2\%). The higher debt ratio of German and French firms suggests the similarity of their CG environment and a closer relationship between firms and lenders. Surprisingly, Japanese firms' market leverage (27.6\%) is on average higher than that of German firms $(23.2 \%)$ and French firms $(21 \%)$. This higher market leverage suggests' reduction in firms' reliance on banks as suppliers of capital and is attributable to a series of corporate governance reforms since 1980. The percentage of women in German (26\%) and French (25\%) firms compared to Japanese firms (4.7\%) show that Japan has one of the lowest board gender quotas among all developed countries. Endo (2020) described the Japanese board as 'old-boy networks. Similarly, the percentage of the outside director is lower in Japan compared to France and Germany. The mean board size and the maximum number of board members are higher in both European countries (see Table 2). 
Table 1 Descriptive statistics: board, firm-level, macroeconomics and institutional variables

\begin{tabular}{|c|c|c|c|c|c|c|c|c|c|c|c|c|}
\hline \multirow[t]{2}{*}{ Variable } & \multicolumn{4}{|l|}{ Japanf } & \multicolumn{4}{|c|}{ Germany } & \multicolumn{4}{|l|}{ France } \\
\hline & Mean & $\mathrm{Sd}$ & Min & Max & Mean & $\mathrm{Sd}$ & Min & Max & Mean & $\mathrm{Sd}$ & Min & Max \\
\hline MkLev & 27.63 & 24.03 & -9.16 & 175 & 0.232 & 0.166 & 0.002 & 0.750 & 0.211 & 0.144 & 0.001 & 0.746 \\
\hline BKLev & 0.182 & 5.20 & -3.03 & 72.2 & 0.201 & 0.179 & 0 & 0.750 & 0.246 & 0.157 & 0.001 & 0.737 \\
\hline BGD & 4.73 & 0.31 & 0 & 1 & 26.31 & 22.93 & 0 & 77 & 25.73 & 17.11 & 0 & 76 \\
\hline ODR & 19.45 & 12.2 & 0 & 100 & 24.28 & 32.68 & 0 & 100 & 25.47 & 18.15 & 0 & 63.64 \\
\hline $\mathrm{BZ}$ & 7.42 & 4.63 & 3 & 16 & 9.22 & 4.42 & 3 & 21 & 10.22 & 4.5 & 3 & 23 \\
\hline BM & 5.14 & 3.05 & 4 & 12 & 5.69 & 1.62 & 4 & 9 & 4.25 & 3.119 & 4 & 12 \\
\hline PROF & 0.02 & 0.0439 & -0.61 & 0.45 & 0.04 & 0.069 & -0.49 & 0.65 & 0.061 & 0.062 & -0.09 & 0.61 \\
\hline Astang & 0.51 & 0.240 & -4.374 & 4.745 & 0.25 & 0.145 & 0.015 & 0.744 & 0.214 & 0.206 & 0.001 & 0.97 \\
\hline FSZ & 17.9 & 1.91 & 13.30 & 26.5 & 14.78 & 1.59 & 11.39 & 19.38 & 14.98 & 1.437 & 12.19 & 19.03 \\
\hline MVB & 1.43 & 1.83 & -48.98 & 39.67 & 1.78 & 1.37 & 0.07 & 10.21 & 2.13 & 1.825 & -5.27 & 16.12 \\
\hline Liq & 2.133 & 2.069 & 0.18 & 58.24 & 1.39 & 0.767 & 0.18 & 5.87 & 1.185 & 1.24 & 0 & 4.52 \\
\hline TX & 0.949 & 12.52 & -139 & 551.2 & 0.18 & 17.59 & -453 & 254.7 & 0.18 & 0.51 & -7.407 & 5.74 \\
\hline STKDEV & 1.62 & 1.26 & 08.67 & 4.54 & 1.32 & 2.13 & 1.98 & 7.83 & 3.01 & 2.87 & 1.63 & 5.62 \\
\hline GDP_GR & 0.79 & 2.35 & -5.62 & 4.89 & 1.41 & 2.49 & 2.3 & 4.38 & 1.26 & 1.52 & -2.79 & 4.53 \\
\hline INF & 0.25 & 1.01 & -1.36 & 2.86 & 1.52 & 0.68 & 0.29 & 2.64 & 1.42 & 0.83 & 0.04 & 2.82 \\
\hline
\end{tabular}

MkLev, Financial debt divided by financial debt + market value of common stock; BKLev, The ratio of the book value of total debt to total assets; BGD, The number of female directors on the board; ODR, Percentage of non-executive directors on the board; BZ, Number of directors on the board; BM, Number of meetings held by the board of directors annually; PROF, The ratio of operating profit to total assets' Book Value; ASTANG, The ratio of fixed assets to total assets; FSZ, Natural log of sales; MVB, Book liabilities plus the market value of equity divided by book value of assets; LIQ, Total Current Asset divided by Total Current Liability; Tx, Current income tax divided income before taxes; STKDEV, Value of listed shares divided by GDP; GDP_GR, Annual growth in gross domestic product; INF, Annual Inflation Rate

Standard errors in parentheses; * $p<0.1$, ** $p<0.05 ; * * * p<0.01$

Table 2 Comparison tests of board variables

\begin{tabular}{lllllllll}
\hline & $\begin{array}{l}\text { France } \\
\text { Mean1 }\end{array}$ & $\begin{array}{l}\text { Japan } \\
\text { Mean2 }\end{array}$ & $\begin{array}{l}T \text {-test } \\
t \text { value }\end{array}$ & $\begin{array}{l}\text { Wilcoxon } \\
z \text { value }\end{array}$ & $\begin{array}{l}\text { Germany } \\
\text { Mean1 }\end{array}$ & $\begin{array}{l}\text { Japan } \\
\text { Mean2 }\end{array}$ & $\begin{array}{l}T \text {-test } \\
t \text { value }\end{array}$ & $\begin{array}{l}\text { Wilcoxon } \\
z \text { value }\end{array}$ \\
\hline MkLev & 0.21 & 27.63 & $-33.02 * * *$ & $-39 * * *$ & 0.23 & 27.63 & $-28.72 * * *$ & $-32.13 * * *$ \\
BKLev & 0.25 & 0.18 & $-0.58 *$ & $12.32 * * *$ & 0.20 & 0.18 & -0.83 & $6.40 * * *$ \\
BGD & 25.73 & 4.73 & $12.1 * * *$ & $45.36 * * *$ & 26.31 & 4.73 & $84.05 * * *$ & $52.23 * * *$ \\
ODR & 25.47 & 19.45 & $09.5 * * *$ & $8.83 * * *$ & 24.28 & 19.45 & $9.8 * * *$ & $-9.15 * * *$ \\
BZ & 10 & 7.42 & $38.2 * * *$ & $38.21 * * *$ & 9.22 & 7.42 & $56.62 * * *$ & $26.72 * * *$ \\
BM & 4.25 & 5.14 & $9.01 * * *$ & $18.01 * * *$ & 5.69 & 5.14 & $-8.18 * * *$ & $-5.51 * * *$ \\
\hline
\end{tabular}

MkLev; Financial debt divided by financial debt + market value of the common stock, BKLev; The ratio of the book value of total debt to total assets, BGD; The number of female directors on the board, ODR; Percentage of non-executive directors on the board, BZ; Number of directors on the board, BM; Number of meetings held by the board of directors annually. Standard errors in parentheses, $* p<0.1,{ }^{*} * p<0.05$, *** $p<0.01$

We used T-Test and Wilcoxon signed-ranked tests to compare the mean of board variables. Our result shows a significant variation of the mean values of board variables obtained from Japanese German and French firms. Furthermore, using a correlation 


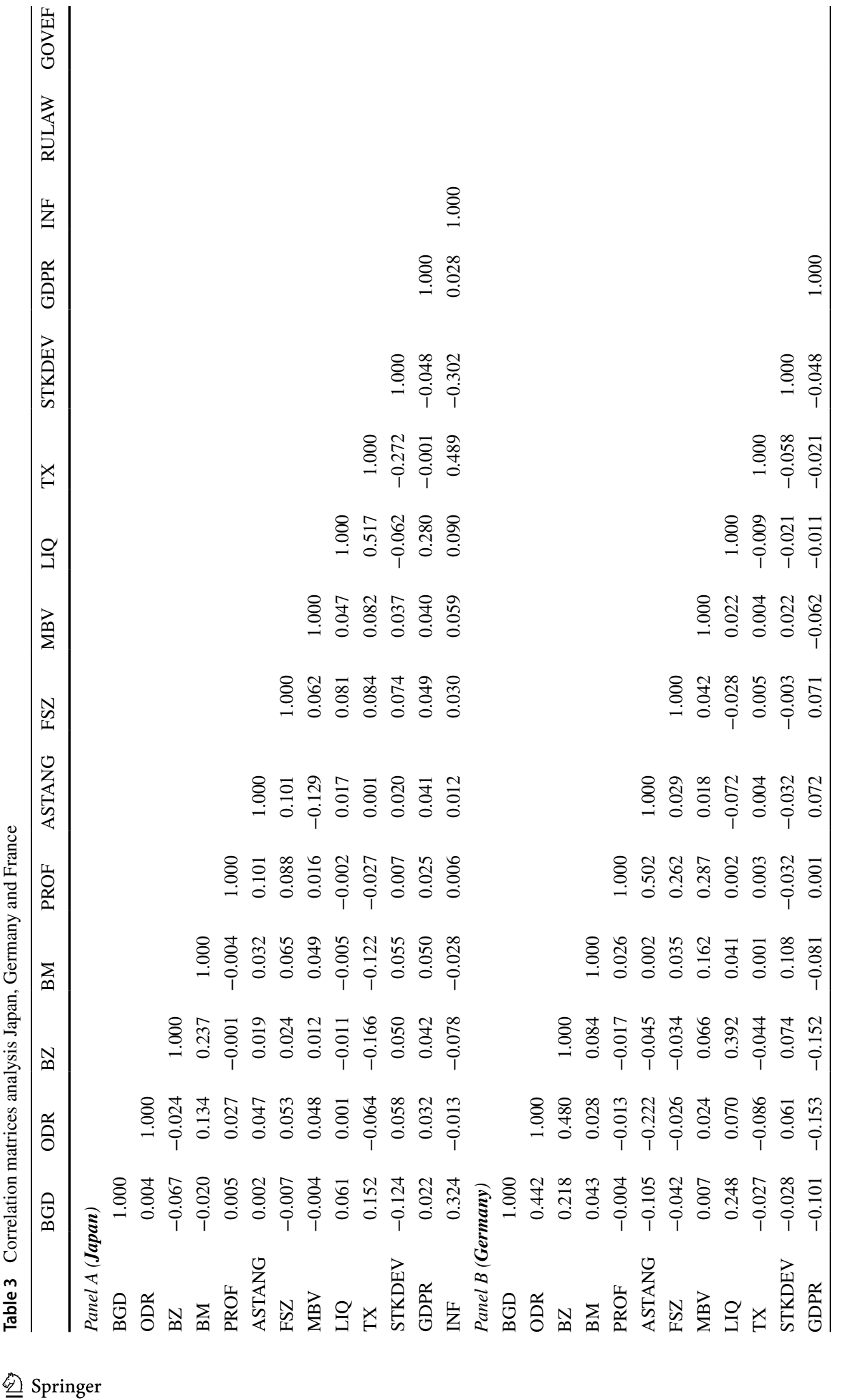




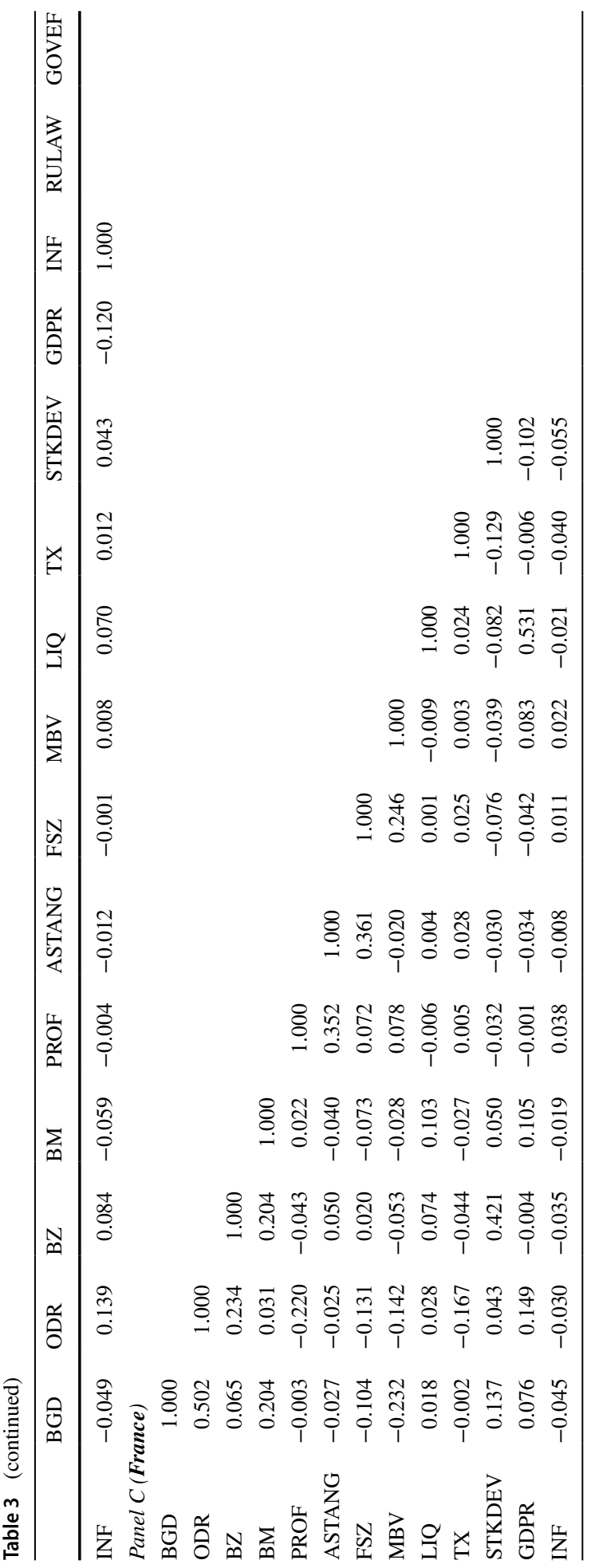


matrix, we tested for multicollinearity among our independent variables. Multicollinearity does not exist in our study since the highest collinearity shown is between tax and liquidity (see Table 3, Panel A).

\subsection{Regression analysis}

We present our study result(using MkLev) for the entire sample in Table 4. Table 5 shows the result of additional analysis using BKLev. We also compared the impact of board mechanisms on the capital structure of EU firms (Germany and France) and Japanese firms in Table 6. We conducted an additional analysis for underleveraged and overleveraged firms in Tables 7 and 8.

We estimate market leverage (MkLev) and book leverage (BKLEV) as a function of board characteristics, institutional and firm characteristics. Consistent with the trade-off theory, we find that the lags of both dependent variables are significant at $1 \%$. This result suggests these firms in our sample dynamically adjust their leverage towards their leverage target. We find an average SOA of 38\% (based on the entire sample). However, after excluding board characteristics and re-estimating Eq. 4, we document SOA of $32 \%$ (see Appendix Table 10).

German firms adjust their leverage at $43 \%$ when we include board variables in our regression. However, we document slightly lower SOA (40\%) after excluding CG variables. Similarly, we find that French firms adjust at the speed of $39 \%$ (including board variables), which slightly reduced by 5 per cent when we exclude CG variables. Interestingly, Japanese firms SOA of $34 \%$ is the lowest among the three countries. This SOA decreased to $31 \%$ after excluding board characteristic, indicating that board characteristics influence speedier adjustment among Japanese, French and German firms. One possible explanation is the role of corporate governance in mitigating agency conflict. The speediest adjustment (with or without CG characteristics) is found among German firms followed by French firms before Japanese firms. This result shows that the variation in the CG environment even among firms in bank-based economies can result in SOA differentials. This variation in the reported SOA is attributable to firms' ability to obtain debt finance. Prior studies show that French and German firm have more access to debt finance since they enjoy a closer relationship with their lenders (Antoniou et al. 2008; Dang 2013). Another explanation for the speedy adjustment of German firms is that the strict separation between management and supervisory board is likely to ensure more effective monitoring resulting in a speedy adjustment of German firms.

We also present the results for all countries in Table 4 and 5. We find that market leverage declines as the women's board participation in the German and French firms increases. However, we found no relationship for Japanese firms, which is in line with our hypothesis. Consistent with debt conservatism suggested by previous studies (Faccio et al. 2016; Hackbarth 2008), our result indicates that the presence of women on the board of German and French firms constrains their use of debt. Previous studies show that women have less appetite for risky decisions (Adusei and Obeng 2019; Faccio et al. 2016; Palvia et al. 2015), including debt issuance (Faccio et al. 2016). Regarding Japan, the low participation of women in the board system may have led to the insignificant relationship between board gender diversity and leverage.

Outside director is negatively related to market leverage in Germany and France but shows a positive relationship with market leverage in Japan. The variation of the result between European (German and French) firms and Japanese firms may be related to 
Table 4 Regression result

\begin{tabular}{|c|c|c|c|c|}
\hline Variables & $\begin{array}{l}\text { Full sample } \\
\text { (1) }\end{array}$ & $\begin{array}{l}\text { Japan } \\
(2)\end{array}$ & $\begin{array}{l}\text { Germany } \\
(5)\end{array}$ & $\begin{array}{l}\text { France } \\
\text { (7) }\end{array}$ \\
\hline & MkLev & MkLev & MkLev & MkLev \\
\hline L.MkLev & $\begin{array}{l}0.6188^{* * * *} \\
(0.0123)\end{array}$ & $\begin{array}{l}0.6528 * * * \\
(0.0228)\end{array}$ & $\begin{array}{l}0.5642 * * * \\
(0.0401)\end{array}$ & $\begin{array}{l}0.6172 * * * \\
(0.0132)\end{array}$ \\
\hline BGD & $\begin{array}{l}-0.0122 * * * \\
(0.0140)\end{array}$ & $\begin{array}{l}-2.3476 \\
(0.4031)\end{array}$ & $\begin{array}{l}-0.0002 * * * \\
(0.0006)\end{array}$ & $\begin{array}{l}-0.0011 \text { *** } \\
(0.0004)\end{array}$ \\
\hline ODR & $\begin{array}{l}-0.0028 \\
(0.0073)\end{array}$ & $\begin{array}{l}0.0054 * * \\
(0.0142)\end{array}$ & $\begin{array}{l}-0.0004 * * \\
(0.0002)\end{array}$ & $\begin{array}{l}-0.0030 * * \\
(0.0001)\end{array}$ \\
\hline BZ & $\begin{array}{l}-0.0041 \\
(0.0127)\end{array}$ & $\begin{array}{l}-0.0181 * \\
(0.0402)\end{array}$ & $\begin{array}{l}-0.0004 * * \\
(0.0015)\end{array}$ & $\begin{array}{l}-0.0012 * * * \\
(0.0011)\end{array}$ \\
\hline BM & $\begin{array}{l}0.0328 \\
(0.0240)\end{array}$ & $\begin{array}{l}0.0423 * \\
(0.0203)\end{array}$ & $\begin{array}{l}-0.0207 * * * \\
(0.0041)\end{array}$ & $\begin{array}{l}-0.0021 \\
(0.0010)\end{array}$ \\
\hline PROF & $\begin{array}{l}-0.0202^{* *} \\
(0.0171)\end{array}$ & $\begin{array}{l}0.0571 \\
(0.143)\end{array}$ & $\begin{array}{l}-0.0314 \\
(0.0573)\end{array}$ & $\begin{array}{l}-0.0641 \\
(0.0326)\end{array}$ \\
\hline Astang & $\begin{array}{l}0.0628 * * * \\
(0.0615)\end{array}$ & $\begin{array}{l}0.0732 \text { *** } \\
(0.0235)\end{array}$ & $\begin{array}{l}0.0427 \\
(0.0177)\end{array}$ & $\begin{array}{l}0.0422 * * * \\
(0.0342)\end{array}$ \\
\hline FSZ & $\begin{array}{l}2.0284 * * * \\
(0.3229)\end{array}$ & $\begin{array}{l}5.3829 * * * \\
(0.3251)\end{array}$ & $\begin{array}{l}-0.0204 * * * \\
(0.0061)\end{array}$ & $\begin{array}{l}-0.0080 * * \\
(0.0034)\end{array}$ \\
\hline MBV & $\begin{array}{l}0.2432 * * * \\
(0.0538)\end{array}$ & $\begin{array}{l}0.2604 * * * \\
(0.0593)\end{array}$ & $\begin{array}{l}0.0027 \\
(0.0053)\end{array}$ & $\begin{array}{l}0.0039 \\
(0.0023)\end{array}$ \\
\hline Liq & $\begin{array}{l}-0.0292 * * * \\
(0.0723)\end{array}$ & $\begin{array}{l}-0.0174 * * \\
(0.0927)\end{array}$ & $\begin{array}{l}0.0269 \\
(0.0162)\end{array}$ & $\begin{array}{l}-0.0035 \\
(0.0024)\end{array}$ \\
\hline TX & $\begin{array}{l}-0.0004 \\
(0.0057)\end{array}$ & $\begin{array}{l}0.0028 \\
(0.0044)\end{array}$ & $\begin{array}{l}-0.0008 \\
(0.0043)\end{array}$ & $\begin{array}{l}-0.0042 \\
(0.0032)\end{array}$ \\
\hline STKDEV & $\begin{array}{l}0.0420 \\
(0.0512)\end{array}$ & $\begin{array}{l}0.00064 \\
(0.002)\end{array}$ & $\begin{array}{l}0.00142 \\
(0.018)\end{array}$ & $\begin{array}{l}0.00131 \\
(0.0025)\end{array}$ \\
\hline GDP_GR & $\begin{array}{l}0.0477 * * \\
(0.0327)\end{array}$ & $\begin{array}{l}0.0274 \\
(0.0112)\end{array}$ & $\begin{array}{l}-0.0007 \\
(0.0014)\end{array}$ & $\begin{array}{l}0.0029 * * \\
(0.0013)\end{array}$ \\
\hline INF & $\begin{array}{l}-0.3228 * * * \\
(0.0604)\end{array}$ & $\begin{array}{l}-0.4226^{* * *} \\
(0.0672)\end{array}$ & $\begin{array}{l}-0.0036 \\
(0.0058)\end{array}$ & $\begin{array}{l}0.0062 \\
(0.0023)\end{array}$ \\
\hline SOA $(\%)$ & SOA 38 & $34 \%$ & $43 \%$ & $39 \%$ \\
\hline AR 1 & 0.001 & 0.017 & 0.029 & 0.037 \\
\hline AR 2 & 0.372 & 0.283 & 0.389 & 0.187 \\
\hline
\end{tabular}

MkLev, Financial debt divided by financial debt + market value of the common stock; BGD, The number of female directors on the board; ODR, Percentage of non-executive directors on the board; BZ, Number of directors on the board; BM, Number of meetings held by the board of directors annually; PROF, The ratio of operating profit to total assets' Book Value; ASTANG, The ratio of fixed assets to total assets; FSZ, Natural log of sales; MVB, Book liabilities plus the market value of equity divided by book value of assets; LIQ, Total Current Asset divided by Total Current Liability; Tx, Current income tax divided income before taxes; STKDEV, Value of listed shares divided by GDP; GDP_GR, Annual growth in gross domestic product; INF, Annual Inflation Rate

Standard errors in parentheses $* p<0.1 ; * * p<0.05 ; * * * p<0.01$ 
Table 5 Additional analysis (BKLEV)

\begin{tabular}{|c|c|c|c|c|}
\hline \multirow[t]{2}{*}{ Variables } & $\begin{array}{l}\text { Full sample } \\
\text { (1) }\end{array}$ & $\begin{array}{l}\text { Japan } \\
(2)\end{array}$ & $\begin{array}{l}\text { Germany } \\
\text { (3) }\end{array}$ & $\begin{array}{l}\text { France } \\
\text { (4) }\end{array}$ \\
\hline & BKLev & BKLev & BKLev & BKLev \\
\hline \multicolumn{5}{|l|}{ L.BKLev } \\
\hline BGD & $\begin{array}{l}-0.0327 * * * \\
(0.0062)\end{array}$ & $\begin{array}{l}-0.0502 \\
(0.0821)\end{array}$ & $\begin{array}{l}-0.0014 * * * \\
(0.0024)\end{array}$ & $\begin{array}{l}-0.0020 * * * \\
(0.0013)\end{array}$ \\
\hline ODR & $\begin{array}{l}0.0007 * * \\
(0.0032)\end{array}$ & $\begin{array}{l}0.0141 * * \\
(0.0076)\end{array}$ & $\begin{array}{l}-0.0024 * * * \\
(0.0028)\end{array}$ & $\begin{array}{l}-0.0002 * * \\
(0.0001)\end{array}$ \\
\hline $\mathrm{BZ}$ & $\begin{array}{l}-0.0071 * \\
(0.0052)\end{array}$ & $\begin{array}{l}-0.0162 * * * \\
(0.0246)\end{array}$ & $\begin{array}{l}-0.0022^{* * *} \\
(0.0005)\end{array}$ & $\begin{array}{l}-0.0080 \\
(0.0006)\end{array}$ \\
\hline BM & $\begin{array}{l}0.0421 \\
(0.0601)\end{array}$ & $\begin{array}{l}0.0224 \\
(0.0742)\end{array}$ & $\begin{array}{l}-0.0060 * * * \\
(0.0051)\end{array}$ & $\begin{array}{l}-0.0014 \\
(0.0203)\end{array}$ \\
\hline PROF & $\begin{array}{l}-0.0307 * * * \\
(0.2623)\end{array}$ & $\begin{array}{l}0.0714 * * * \\
(0.4271)\end{array}$ & $\begin{array}{l}-0.0161 * * * \\
(0.0427)\end{array}$ & $\begin{array}{l}-0.0651^{* *} \\
(0.0497)\end{array}$ \\
\hline Astang & $\begin{array}{l}0.0774 * * * \\
(0.3262)\end{array}$ & $\begin{array}{l}0.0988^{* * *} \\
(0.5437)\end{array}$ & $\begin{array}{l}0.0466 \\
(0.1245)\end{array}$ & $\begin{array}{l}0.0671 \\
(0.0637)\end{array}$ \\
\hline FSZ & $\begin{array}{l}0.1023 * * * \\
(0.1281)\end{array}$ & $\begin{array}{l}0.0530 \text { *** } \\
(0.0308)\end{array}$ & $\begin{array}{l}-0.0419 * * * \\
(0.0061)\end{array}$ & $\begin{array}{l}-0.0389 * * \\
(0.0049)\end{array}$ \\
\hline MBV & $\begin{array}{l}0.0562 * * \\
(0.0206)\end{array}$ & $\begin{array}{l}0.0204 * * * \\
(0.0245)\end{array}$ & $\begin{array}{l}0.0028 \\
(0.0042)\end{array}$ & $\begin{array}{l}0.0046 * \\
(0.0017)\end{array}$ \\
\hline Liq & $\begin{array}{l}-0.0116^{* * * *} \\
(0.0348)\end{array}$ & $\begin{array}{l}-0.0157 * * * \\
(0.0402)\end{array}$ & $\begin{array}{l}-0.0125 \\
(0.0379)\end{array}$ & $\begin{array}{l}-0.0024 \\
(0.0034)\end{array}$ \\
\hline $\mathrm{TX}$ & $\begin{array}{l}0.0034 \\
(0.0029)\end{array}$ & $\begin{array}{l}0.0076^{* * *} \\
(0.0031)\end{array}$ & $\begin{array}{l}-0.0083 \\
(0.0003)\end{array}$ & $\begin{array}{l}-0.0029 \\
(0.0055)\end{array}$ \\
\hline STKDEV & $\begin{array}{l}-0.00211 \\
(0.014)\end{array}$ & $\begin{array}{l}-0.00248 \\
(0.005)\end{array}$ & $\begin{array}{l}-0.0047 \\
(0.0016)\end{array}$ & $\begin{array}{l}0.00053 \\
(0.0003)\end{array}$ \\
\hline GDP_GR & $\begin{array}{l}-0.0327 \\
(0.0354)\end{array}$ & $\begin{array}{l}-0.0425 \\
(0.0145)\end{array}$ & $\begin{array}{l}0.0016 \\
(0.0030)\end{array}$ & $\begin{array}{l}-0.0003 \\
(0.0034)\end{array}$ \\
\hline INF & $\begin{array}{l}-0.0302 \\
(0.0446)\end{array}$ & $\begin{array}{l}-0.0643 * \\
(0.0308)\end{array}$ & $\begin{array}{l}-0.0125^{* *} \\
(0.0049)\end{array}$ & $\begin{array}{l}0.0006 \\
(0.0021)\end{array}$ \\
\hline
\end{tabular}

BKLev; The ratio of the book value of total debt to total assets, BGD; The number of female directors on the board, ODR; Percentage of non-executive directors on the board, BZ; Number of directors on the board, BM; Number of meetings held by the board of directors annually, PROF; The ratio of operating profit to total assets' Book Value, ASTANG; The ratio of fixed assets to total assets, FSZ; Natural log of sales, MVB; Book liabilities plus the market value of equity divided by book value of assets, LIQ; Total Current Asset divided by Total Current Liability, Tx; Current income tax divided income before taxes, STKDEV; Value of listed shares divided by GDP, GDP_GR; Annual growth in gross domestic product, INF; Annual Inflation Rate Standard errors in parentheses $* p<0.1, * * p<0.05, * * * p<0.01$

different roles of outside directors within this system. Miwa and Ramseyer (2005) argue that Japanese outside directors span boundary and offer their helpful expertise end valuable connection to firms they serve. In Germany and France, outside directors' control function (Kim et al. 2007) may have led to the inverse relationship with market leverage. 
Table 6 Additional analysis (Japan and EU)

\begin{tabular}{|c|c|c|}
\hline \multirow[t]{2}{*}{ Variables } & $\begin{array}{l}\text { Japan } \\
(1)\end{array}$ & $\begin{array}{l}\text { EU Countries } \\
\text { (3) }\end{array}$ \\
\hline & MkLev & MkLev \\
\hline \multirow[t]{2}{*}{ L.MkLev } & $0.6220 * * *$ & $0.4354 * * *$ \\
\hline & $(0.0148)$ & $(0.0381)$ \\
\hline \multirow[t]{2}{*}{ BGD } & 0.0271 & $-0.0035 * * *$ \\
\hline & $(0.0504)$ & $(0.0002)$ \\
\hline \multirow[t]{2}{*}{ ODR } & $0.0045^{* *}$ & $-0.0004 * * *$ \\
\hline & $(0.0133)$ & $(0.0001)$ \\
\hline \multirow[t]{2}{*}{$\mathrm{BZ}$} & $-0.0939 *$ & $-0.0005^{* * *}$ \\
\hline & $(0.0403)$ & $(0.0024)$ \\
\hline \multirow[t]{2}{*}{$\mathrm{BM}$} & 0.0332 & $-0.0022 * * *$ \\
\hline & $(0.0108)$ & $(0.0032)$ \\
\hline \multirow[t]{2}{*}{ PROF } & 0.0361 & -0.0348 \\
\hline & $(0.0452)$ & $(0.0302)$ \\
\hline \multirow[t]{2}{*}{ Astang } & $-0.032 * * *$ & 0.0372 \\
\hline & $(0.2233)$ & $(0.0562)$ \\
\hline \multirow[t]{2}{*}{ FSZ } & $0.060 * * *$ & $-0.0253^{* * *}$ \\
\hline & $(0.3524)$ & $(0.0025)$ \\
\hline \multirow[t]{2}{*}{ MVB } & $0.0804 * * *$ & $0.0046^{* *}$ \\
\hline & $(0.0482)$ & $(0.0167)$ \\
\hline \multirow[t]{2}{*}{ Liq } & $-0.1545^{* *}$ & 0.0421 \\
\hline & $(0.0722)$ & $(0.0032)$ \\
\hline \multirow[t]{2}{*}{$\mathrm{TX}$} & 0.0054 & -0.0023 \\
\hline & $(0.0067)$ & $(0.0004)$ \\
\hline \multirow[t]{2}{*}{ STKDEV } & 0.00054 & 0.0061 \\
\hline & $(0.002)$ & $(0.0082)$ \\
\hline \multirow[t]{2}{*}{ GDP_GR } & 0.0633 & -0.0003 \\
\hline & $(0.0524)$ & $(0.0820)$ \\
\hline \multirow[t]{2}{*}{ INF } & $-0.0527 * * *$ & -0.0035 \\
\hline & $(0.0452)$ & $(0.0082)$ \\
\hline
\end{tabular}

MkLev, Financial debt divided by financial debt + market value of the common stock; BGD, The number of female directors on the board; ODR, Percentage of non-executive directors on the board; BZ, Number of directors on the board; BM, Number of meetings held by the board of directors annually; PROF, The ratio of operating profit to total assets' Book Value; ASTANG, The ratio of fixed assets to total assets; FSZ, Natural log of sales; MVB, Book liabilities plus the market value of equity divided by book value of assets; LIQ, Total Current Asset divided by Total Current Liability; Tx, Current income tax divided income before taxes; STKDEV, Value of listed shares divided by GDP; GDP_GR, Annual growth in gross domestic product; INF, Annual Inflation Rate

Standard errors in parentheses $* p<0.1 ; * * p<0.05$; *** $p<0.01$ 
Table 7 Additional analysisunderleveraged firms

\begin{tabular}{|c|c|c|c|c|}
\hline Variables & $\begin{array}{l}\text { Full sample } \\
\text { (1) }\end{array}$ & $\begin{array}{l}\text { Japan } \\
(2)\end{array}$ & $\begin{array}{l}\text { German } \\
\text { (3) }\end{array}$ & $\begin{array}{l}\text { France } \\
\text { (4) }\end{array}$ \\
\hline & MkLev & MkLev & MkLev & MkLev \\
\hline L.MkLev & $\begin{array}{l}0.6013 * * * \\
(0.0354)\end{array}$ & $\begin{array}{l}0.7117 * * * \\
(0.0165)\end{array}$ & $\begin{array}{l}0.6128 * * * \\
(0.0338)\end{array}$ & $\begin{array}{l}0.6331 * * * \\
(0.0531)\end{array}$ \\
\hline BGD & $\begin{array}{l}-0.0035 \\
(0.0052)\end{array}$ & $\begin{array}{l}-0.0526 \\
(0.0942)\end{array}$ & $\begin{array}{l}-0.0004 * \\
(0.0032)\end{array}$ & $\begin{array}{l}-0.007 * * \\
(0.0004)\end{array}$ \\
\hline ODR & $\begin{array}{l}-0.0006 \\
(0.0027)\end{array}$ & $\begin{array}{l}-0.0046 \\
(0.0229)\end{array}$ & $\begin{array}{l}0.0004 \\
(0.0008)\end{array}$ & $\begin{array}{l}-0.0003 \\
(0.0014)\end{array}$ \\
\hline BZ & $\begin{array}{l}-0.0051 \\
(0.0062)\end{array}$ & $\begin{array}{l}-0.0120 \\
(0.0472)\end{array}$ & $\begin{array}{l}-0.0002 \\
(0.0032)\end{array}$ & $\begin{array}{l}-0.0007 \\
(0.0006)\end{array}$ \\
\hline $\mathrm{BM}$ & $\begin{array}{l}-0.0226 \\
(0.0175)\end{array}$ & $\begin{array}{l}0.0043 \\
(0.0453)\end{array}$ & $\begin{array}{l}0.0013 \\
(0.0024)\end{array}$ & $\begin{array}{l}0.0006 \\
(0.0009)\end{array}$ \\
\hline PROF & $\begin{array}{l}-0.023 * * * \\
(0.0214)\end{array}$ & $\begin{array}{l}-0.0432 * * * \\
(0.0473)\end{array}$ & $\begin{array}{l}-0.0124 \\
(0.0216)\end{array}$ & $\begin{array}{l}-0.053 * * * \\
(0.0325)\end{array}$ \\
\hline Astang & $\begin{array}{l}-0.0263 * * * \\
(0.2405)\end{array}$ & $\begin{array}{l}-0.0466^{* * * *} \\
(0.3403)\end{array}$ & $\begin{array}{l}-0.0051 \\
(0.0425)\end{array}$ & $\begin{array}{l}-0.0731 \\
(0.0424)\end{array}$ \\
\hline FSZ & $\begin{array}{l}0.0206 * * * \\
(0.0783)\end{array}$ & $\begin{array}{l}0.0365^{* * *} \\
(0.5103)\end{array}$ & $\begin{array}{l}0.0023 \\
(0.0042)\end{array}$ & $\begin{array}{l}0.0072 * * \\
(0.0032)\end{array}$ \\
\hline MVB & $\begin{array}{l}0.0073 \\
(0.0346)\end{array}$ & $\begin{array}{l}0.0572 \\
(0.0865)\end{array}$ & $\begin{array}{l}0.0085 \\
(0.0043)\end{array}$ & $\begin{array}{l}-0.0039 \\
(0.0038)\end{array}$ \\
\hline Liq & $\begin{array}{l}-0.0628^{*} \\
(0.0475)\end{array}$ & $\begin{array}{l}-0.0471 \\
(0.0586)\end{array}$ & $\begin{array}{l}-0.0023 \\
(0.0324)\end{array}$ & $\begin{array}{l}-0.0040 \\
(0.0062)\end{array}$ \\
\hline TX & $\begin{array}{l}-0.0046 \\
(0.0041)\end{array}$ & $\begin{array}{l}-0.0082 \\
(0.0061)\end{array}$ & $\begin{array}{l}-0.0062 \\
(0.0008)\end{array}$ & $\begin{array}{l}-0.0005 \\
(0.0041)\end{array}$ \\
\hline STKDEV & $\begin{array}{l}0.0011 \\
(0.0010)\end{array}$ & $\begin{array}{l}-0.0027 \\
(0.0021)\end{array}$ & $\begin{array}{l}-0.0037 \\
(0.0042)\end{array}$ & $\begin{array}{l}-0.0011 \\
(0.0040)\end{array}$ \\
\hline GDP_GR & $\begin{array}{l}0.0186 \\
(0.0126)\end{array}$ & $\begin{array}{l}-0.0042 \\
(0.0282)\end{array}$ & $\begin{array}{l}0.0002 \\
(0.0031)\end{array}$ & $\begin{array}{l}0.0059 * * * \\
(0.0120)\end{array}$ \\
\hline INF & $\begin{array}{l}0.0533 \\
(0.0116)\end{array}$ & $\begin{array}{l}-0.0684 * * * \\
(0.0536)\end{array}$ & $\begin{array}{l}-0.0055 \\
(0.00432)\end{array}$ & $\begin{array}{l}0.0027 \\
(0.0016)\end{array}$ \\
\hline
\end{tabular}

MkLev; Financial debt divided by financial debt + market value of the common stock, BGD; The number of female directors on the board, ODR; Percentage of non-executive directors on the board, BZ; Number of directors on the board, BM; Number of meetings held by the board of directors annually, PROF; The ratio of operating profit to total assets' Book Value, ASTANG; The ratio of fixed assets to total assets, FSZ; Natural log of sales, MVB; Book liabilities plus the market value of equity divided by book value of assets, LIQ; Total Current Asset divided by Total Current Liability, Tx; Current income tax divided income before taxes, STKDEV; Value of listed shares divided by GDP, GDP_GR; Annual growth in gross domestic product, INF; Annual Inflation Rate

Standard errors in parentheses $* p<0.1, * * p<0.05, * * * p<0.01$ 
Table 8 Additional analysis -overleveraged firms

\begin{tabular}{|c|c|c|c|c|}
\hline Variables & $\begin{array}{l}\text { Full sample } \\
\text { (1) }\end{array}$ & $\begin{array}{l}\text { Japan } \\
\text { (3) }\end{array}$ & $\begin{array}{l}\text { German } \\
\text { (5) }\end{array}$ & $\begin{array}{l}\text { France } \\
\text { (7) }\end{array}$ \\
\hline & MkLev & MkLev & MkLev & MkLev \\
\hline L.MkLev & $\begin{array}{l}0.6251 * * * \\
(0.0631)\end{array}$ & $\begin{array}{l}0.7266 * * * \\
(0.0527)\end{array}$ & $\begin{array}{l}0.5662 * * * \\
(0.0752)\end{array}$ & $\begin{array}{l}0.6592 * * * \\
(0.0461)\end{array}$ \\
\hline BGD & $\begin{array}{l}0.0802 \\
(0.0306)\end{array}$ & $\begin{array}{l}-0.7715 \\
(0.0126)\end{array}$ & $\begin{array}{l}-0.0048^{*} \\
(0.0044)\end{array}$ & $\begin{array}{l}-0.0052 * \\
(0.0014)\end{array}$ \\
\hline ODR & $\begin{array}{l}-0.0062 \\
(0.0348)\end{array}$ & $\begin{array}{l}0.0361 * \\
(0.0124)\end{array}$ & $\begin{array}{l}0.0023 \\
(0.0014)\end{array}$ & $\begin{array}{l}0.0116 \\
(0.0034)\end{array}$ \\
\hline BZ & $\begin{array}{l}-0.0704 * * \\
(0.0266)\end{array}$ & $\begin{array}{l}-0.0219 \text { *** } \\
(0.0836)\end{array}$ & $\begin{array}{l}0.0006 \\
(0.0004)\end{array}$ & $\begin{array}{l}-0.0029 \\
(0.0021)\end{array}$ \\
\hline BM & $\begin{array}{l}-0.0416 \\
(0.0422)\end{array}$ & $\begin{array}{l}0.0104 \\
(0.0443)\end{array}$ & $\begin{array}{l}-0.0023 \\
(0.0211)\end{array}$ & $\begin{array}{l}-0.0061 * * * \\
(0.0065)\end{array}$ \\
\hline PROF & $\begin{array}{l}-0.7612 \\
(0.1716)\end{array}$ & $\begin{array}{l}0.0743 * * * \\
(0.2543)\end{array}$ & $\begin{array}{l}-0.0546 * * * \\
(0.0845)\end{array}$ & $\begin{array}{l}-0.0375^{* * * *} \\
(0.0732)\end{array}$ \\
\hline Astang & $\begin{array}{l}-0.0794 * * * \\
(0.3934)\end{array}$ & $\begin{array}{l}-0.0813 \text { *** } \\
(0.4383)\end{array}$ & $\begin{array}{l}-0.0329 * * * \\
(0.0754)\end{array}$ & $\begin{array}{l}-0.0731 \\
(0.0431)\end{array}$ \\
\hline FSZ & $\begin{array}{l}0.0804 * * * \\
(0.0684)\end{array}$ & $\begin{array}{l}0.0482 * * * \\
(0.0431)\end{array}$ & $\begin{array}{l}-0.0343 * * * \\
(0.0073)\end{array}$ & $\begin{array}{l}-0.0204 * * \\
(0.0065)\end{array}$ \\
\hline MVB & $\begin{array}{l}0.04216^{* * * *} \\
(0.0932)\end{array}$ & $\begin{array}{l}0.0577 \\
(0.0453)\end{array}$ & $\begin{array}{l}0.0031 \\
(0.0031)\end{array}$ & $\begin{array}{l}0.0207 * * * \\
(0.0059)\end{array}$ \\
\hline Liq & $\begin{array}{l}-0.0321 * * * \\
(0.2252)\end{array}$ & $\begin{array}{l}-0.0912^{* * *} \\
(0.4276)\end{array}$ & $\begin{array}{l}0.0648 * * * \\
(0.0246)\end{array}$ & $\begin{array}{l}-0.0213^{*} \\
(0.0261)\end{array}$ \\
\hline $\mathrm{TX}$ & $\begin{array}{l}-0.0027 \\
(0.0126)\end{array}$ & $\begin{array}{l}-0.0057 \\
(0.0287)\end{array}$ & $\begin{array}{l}-0.0036^{* *} \\
(0.0061)\end{array}$ & $\begin{array}{l}-0.0052 \\
(0.0054)\end{array}$ \\
\hline STKDEV & $\begin{array}{l}0.0010 \\
(0.0020)\end{array}$ & $\begin{array}{l}-0.0048 \\
(0.0059)\end{array}$ & $\begin{array}{l}-0.0031 \\
(0.0031)\end{array}$ & $\begin{array}{l}-0.0010 \\
(0.0029)\end{array}$ \\
\hline GDP_GR & $\begin{array}{l}0.0672 * \\
(0.0526)\end{array}$ & $\begin{array}{l}0.0520 \\
(0.0680)\end{array}$ & $\begin{array}{l}-0.0028 * * \\
(0.0027)\end{array}$ & $\begin{array}{l}0.0027 \\
(0.0015)\end{array}$ \\
\hline INF & $\begin{array}{l}-0.6456^{* * * *} \\
(0.0838)\end{array}$ & $\begin{array}{l}-0.8915 * * * \\
(0.2025)\end{array}$ & $\begin{array}{l}0.0025 \\
(0.0067)\end{array}$ & $\begin{array}{l}0.0043 \\
(0.0072)\end{array}$ \\
\hline
\end{tabular}

MkLev, Financial debt divided by financial debt + market value of the common stock; BGD, The number of female directors on the board; ODR, Percentage of non-executive directors on the board; BZ, Number of directors on the board; BM, Number of meetings held by the board of directors annually; PROF, The ratio of operating profit to total assets' Book Value; ASTANG, The ratio of fixed assets to total assets; FSZ, Natural log of sales; MVB, Book liabilities plus the market value of equity divided by book value of assets; LIQ, Total Current Asset divided by Total Current Liability; Tx, Current income tax divided income before taxes; STKDEV, Value of listed shares divided by GDP; GDP_GR, Annual growth in gross domestic product; INF, Annual Inflation Rate

Standard errors in parentheses $* p<0.1 ; * * p<0.05$; *** $p<0.01$ 
Board size is negatively related to the market leverage in Japan, German and France, meaning that the size of the board reduces the use of leverage in a bank-based (stakeholderoriented) economy. We also document a higher statistical relationship for German and French firms and a weaker relationship for Japanese firms. This relationship is expected for German, French and Japanese firms due to the relatively large board among in stakeholder-oriented CG environment, including a significant level of representation from the employees.

Board meeting is inversely related to market leverage in Germany, implying that frequent meeting of board members constrains debt usage in these countries. This result contradicts our expectation of a positive relationship. As expected, we found a positive relationship between board meeting and leverage among Japanese firms. Lorca et al. (2011) show that board meeting frequency results in a lower lending cost, thereby influencing lenders' risk assessment. Other studies have suggested that the frequency of board meetings signals its monitoring ability (Adams and Ferreira 2009; Hahn and Lasfer 2016), which is likely to influence lenders assessment of the company. Furthermore, we found no relationship between board meetings and market leverage among French firms, which may be due to the voluntary nature of boards meeting in France in line with Viénot (1999) recommendation.

\subsection{Additional analysis}

We conducted an additional analysis using book leverage. We found that board gender diversity is inversely related to book leverage in Germany and France but show no relationship for Japanese firms. Similar to our main result, outside directors have a positive relationship with book leverage among Japanese firms but shows a negative relationship for German and French firms. Board size is also negatively related to book leverage in Japan and Germany. We document a similar result after separating our sample into EU countries (France and Germany) and Japan.

Board gender diversity is inversely related to MkLev for overleveraged and underleveraged European firms. Also, outside directors are positively related to market leverage for Japanese (overleveraged) firms, while board size shows a negative relationship with market leverage.

\section{Conclusion}

In this study, we examine and compares the impact of board characteristics on the capital structure and speed of adjustment of Japanese, German and French firms. This study is important because these three countries have distinct corporate governance environment but also remarkable differences in their corporate governance environment.

We show that board characteristics influence speedier adjustment for Japanese, French and German firms. This result may be due to the role of corporate governance in mitigating agency conflict. The speediest adjustment (with or without CG characteristics) is found among German firms followed by French firms before Japanese firms, confirming the variation in the $\mathrm{CG}$ environment even among firms in bank-based economies. 
We found an inverse relationship between board gender diversity and leverage for German and French firms on the relationship between board characteristics and leverage. We found no relationship with Japanese firms. Outside director is negatively related to market leverage in Germany and France but shows a positive relationship with market leverage in Japan. Board size is negatively related to the market leverage in all three countries, while board meeting is negatively related to leverage in Germany. We found a similar result after employing book leverage.

Our finding makes a significant contribution since it shows the varying impact of board characteristics on firms' capital structure in these bank-based economies. Additionally, the inverse relationship between board gender diversity and market leverage in France and Germany is relevant for the composition of corporate boards. It shows the needs for women's involvement on the corporate board.

Although our study focuses on the three most developed bank-based economies, future studies may benefit from a larger sample involving other bank-based countries. It would also be interesting to examine the impact of board characteristics on firms' capital structure in developing countries.

\section{Appendix}

See Tables 9 and 10 .

Table 9 Measurement of variables

\begin{tabular}{|c|c|c|}
\hline Variables & Definition & Measurement \\
\hline MKLEV & Market Leverage & $\begin{array}{l}\text { Financial debt divided by financial debt }+ \text { market value of com- } \\
\text { mon stock }\end{array}$ \\
\hline BKLEV & Book Leverage & The ratio of the book value of total debt to total assets \\
\hline BGD & Board Gender Diversity & The number of female directors on the board \\
\hline ODR & Board Independence & Percentage of non-executive directors on the board \\
\hline BZ & Board Size & Number of directors on the board \\
\hline BM & Board Meeting & Number of meetings held by the board of directors annually \\
\hline PROF & Profitability & The ratio of operating profit to total assets' Book Value \\
\hline ASTANG & Asset Tangibility & The ratio of fixed assets to total assets \\
\hline FSZ & Firm Size & Natural log of sales \\
\hline MVB & Growth Opportunity & $\begin{array}{l}\text { Book liabilities plus the market value of equity divided by book } \\
\text { value of assets }\end{array}$ \\
\hline LIQ & Liquidity & Total Current Asset divided by Total Current Liability \\
\hline TX & Tax & Current Income Tax divided by income before taxes \\
\hline STKDEV & Stock Market Development & The value of listed shares divided by GDP \\
\hline GDP_GR & Gross Domestic Product & Annual growth in gross domestic product \\
\hline INF & Inflation & Annual Inflation Rate \\
\hline
\end{tabular}


Table 10 Regression result (without board variables)

\begin{tabular}{|c|c|c|c|c|}
\hline \multirow[t]{2}{*}{ Variables } & $\begin{array}{l}\text { Full sample } \\
\text { (1) }\end{array}$ & $\begin{array}{l}\text { Japan } \\
(2)\end{array}$ & $\begin{array}{l}\text { Germany } \\
\text { (5) }\end{array}$ & $\begin{array}{l}\text { France } \\
\text { (7) }\end{array}$ \\
\hline & MkLev & MkLev & MkLev & MkLev \\
\hline L.MkLev & $\begin{array}{l}0.680 * * * \\
(0.035)\end{array}$ & $\begin{array}{l}0.692 * * * \\
(0.037)\end{array}$ & $\begin{array}{l}0.597 * * * \\
(0.062)\end{array}$ & $\begin{array}{l}0.664 * * * \\
(0.069)\end{array}$ \\
\hline PROF & $\begin{array}{l}-0.036^{* * *} \\
(0.075)\end{array}$ & $\begin{array}{l}-0.045^{* * * *} \\
(0.043)\end{array}$ & $\begin{array}{l}-0.054^{*} \\
(0.061)\end{array}$ & $\begin{array}{l}-0.0408 \\
(0.039)\end{array}$ \\
\hline Astang & $\begin{array}{l}-0.051^{* * * *} \\
(0.043)\end{array}$ & $\begin{array}{l}-0.067 * * * \\
(0.028)\end{array}$ & $\begin{array}{l}0.082 \\
(0.073)\end{array}$ & $\begin{array}{l}0.064 * * * \\
(0.055)\end{array}$ \\
\hline FSZ & $\begin{array}{l}0.074 * * * \\
(0.052)\end{array}$ & $\begin{array}{l}0.0602 * * * \\
(0.031)\end{array}$ & $\begin{array}{l}-0.048^{* * * *} \\
(0.038)\end{array}$ & $\begin{array}{l}-0.03 * * * \\
(0.025)\end{array}$ \\
\hline MBV & $\begin{array}{l}0.047 * * * \\
(0.074)\end{array}$ & $\begin{array}{l}0.028 * * * \\
(0.051)\end{array}$ & $\begin{array}{l}0.032 \\
(0.036)\end{array}$ & $\begin{array}{l}0.042 \\
(0.013)\end{array}$ \\
\hline Liq & $\begin{array}{l}-0.051 * * * \\
(0.07)\end{array}$ & $\begin{array}{l}-0.714 \\
(0.058)\end{array}$ & $\begin{array}{l}0.064 \\
(0.029)\end{array}$ & $\begin{array}{l}0.012 \\
(0.026)\end{array}$ \\
\hline TX & $\begin{array}{l}-0.023 \\
(0.023)\end{array}$ & $\begin{array}{l}-0.0047 \\
(0.0183)\end{array}$ & $\begin{array}{l}-0.0032 * * \\
(0.0012)\end{array}$ & $\begin{array}{l}-0.0074 \\
(0.0026)\end{array}$ \\
\hline STKDEV & $\begin{array}{l}0.0833 \\
(0.067)\end{array}$ & $\begin{array}{l}0.0072 \\
(0.003)\end{array}$ & $\begin{array}{l}0.0028 \\
(0.004)\end{array}$ & $\begin{array}{l}0.0002 \\
(0.021)\end{array}$ \\
\hline GDP_GR & $\begin{array}{l}0.028 * \\
(0.013)\end{array}$ & $\begin{array}{l}0.023 \\
(0.022)\end{array}$ & $\begin{array}{l}-0.083 \\
(0.043)\end{array}$ & $\begin{array}{l}0.094 \\
(0.052)\end{array}$ \\
\hline INF & $\begin{array}{l}-0.227 * * * \\
(0.059)\end{array}$ & $\begin{array}{l}-0.581 * * * \\
(0.086)\end{array}$ & $\begin{array}{l}0.073 \\
(0.035)\end{array}$ & $\begin{array}{l}-0.082 \\
(0.092)\end{array}$ \\
\hline SOA $(\%)$ & SOA 32 & $31 \%$ & $40 \%$ & $34 \%$ \\
\hline AR 1 & 0.001 & 0.033 & 0.002 & 0.014 \\
\hline AR 2 & 0.351 & 0.142 & 0.239 & 0.411 \\
\hline
\end{tabular}

MkLev, Financial debt divided by financial debt + market value of the common stock; BGD, The number of female directors on the board; ODR, Percentage of non-executive directors on the board; BZ, Number of directors on the board; BM, Number of meetings held by the board of directors annually; PROF, The ratio of operating profit to total assets' Book Value; ASTANG, The ratio of fixed assets to total assets; FSZ, Natural log of sales; MVB, Book liabilities plus the market value of equity divided by book value of assets; LIQ, Total Current Asset divided by Total Current Liability; Tx, Current income tax divided income before taxes; STKDEV, Value of listed shares divided by GDP; GDP_GR, Annual growth in gross domestic product; INF, Annual Inflation Rate

Standard errors in parentheses $* p<0.1 ; * * p<0.05$; *** $p<0.01$

Open Access This article is licensed under a Creative Commons Attribution 4.0 International License, which permits use, sharing, adaptation, distribution and reproduction in any medium or format, as long as you give appropriate credit to the original author(s) and the source, provide a link to the Creative Commons licence, and indicate if changes were made. The images or other third party material in this article are included in the article's Creative Commons licence, unless indicated otherwise in a credit line to the material. If material is not included in the article's Creative Commons licence and your intended use is not permitted by statutory regulation or exceeds the permitted use, you will need to obtain permission directly from the copyright holder. To view a copy of this licence, visit http://creativecommons.org/licenses/by/4.0/. 


\section{References}

Adams RB, Ferreira D (2009) Women in the boardroom and their impact on governance and performance. J Financ Econ 94(2):291-309

Adusei M, Obeng EYT (2019) Board gender diversity and the capital structure of microfinance institutions: A global analysis. Q Rev Econ Finance 71:258-269. https://doi.org/10.1016/j.qref.2018.09.006

Antal AB, Sobczak A (2007) Corporate social responsibility in France: A mix of national traditions and international influences. Bus Soc 46(1):9-32

Antoniou A, Guney Y, Paudyal K (2008) The determinants of capital structure: capital market-oriented versus bank-oriented institutions. J Financ Quantitative Ana 43:59-92

Aoki M (2010) Corporations in evolving diversity: Cognition, governance, and institutions. Oxford University Press, Oxford

Arellano M, Bond S (1991) Some tests of specification for panel data: Monte Carlo evidence and an application to employment equations. Rev Econ Stud 58(2):277-297

Barnea A, Haugen RA, Senbet LW (1981) Market imperfections, agency problems, and capital structure: a review. Financ Manag 10:7-22

Bats JV, Houben AC (2020) Bank-based versus market-based financing: implications for systemic risk. J Banking Financ 114:105776

Beck T, Levine R (2002) Industry growth and capital allocation: does having a market-or bank-based system matter? J Financ Econ 64(2):147-180

Becker-Blease JR, Irani AJ (2008) Do corporate governance attributes affect adverse selection costs? Evidence from seasoned equity offerings. Rev Quant Financ Acc 30(3):281-296

Blundell R, Bond S (1998) Initial conditions and moment restrictions in dynamic panel data models. J Econom 87(1):115-143

Brick IE, Chidambaran NK (2010) Board meetings, committee structure, and firm value. J Corp Finan 16(4):533-553. https://doi.org/10.1016/j.jcorpfin.2010.06.003

Byoun S (2008) How and when do firms adjust their capital structures toward targets? J Financ 63(6):3069-3096

Campbell K, Mínguez-Vera A (2008) Gender diversity in the boardroom and firm financial performance. J Bus Ethics 83(3):435-451

Cao J, Cui Y (2021) Trade Credit and Capital Structure Adjustment Speed: Evidence From Chinese Listed Firms. Rev Pacific Basin Financ Markets Policies 24:2150002

Chakraborty S, Ray T (2006) Bank-based versus market-based financial systems: A growth-theoretic analysis. J Monet Econ 53(2):329-350

Chang X, Dasgupta S (2009) Target behavior and financing: how conclusive is the evidence? J Financ 64(4):1767-1796

Cheng S (2008) Board size and the variability of corporate performance. J Financ Econ 87(1):157-176

Cheng S, Evans JH, Nagarajan NJ (2008) Board size and firm performance: the moderating effects of the market for corporate control. Rev Quant Financ Acc 31(2):121-145

Closset F, Urban D (2019) The balance of power between creditors and the firm: Evidence from German insolvency law. J Corp Finan 58:454-477

Coles JL, Daniel ND, Naveen L (2008) Boards: Does one size fit all? J Financ Econ 87(2):329-356

Conyon MJ, Peck SI (1998) Board size and corporate performance: evidence from European countries. Eur J Financ 4(3):291-304

Cook DO, Tang T (2010) Macroeconomic conditions and capital structure adjustment speed. J Corp Finan 16(1):73-87

Cromme G (2005) Corporate governance in Germany and the German corporate governance code. Corporate Governance: an International Review 13(3):362-367

Dang VA (2013) Testing capital structure theories using error correction models: evidence from the UK, France and Germany. Appl Econom 45(2):171-190

Dang VA, Kim M, Shin Y (2012) Asymmetric capital structure adjustments: New evidence from dynamic panel threshold models. J Empir Financ 19(4):465-482

Dang VA, Kim M, Shin Y (2014) Asymmetric adjustment toward optimal capital structure: Evidence from a crisis. Int Rev Financ Anal 33:226-242

De Miguel A, Pindado J (2001) Determinants of capital structure: new evidence from Spanish panel data. J Corp Finan 7(1):77-99

De Villiers C, Naiker V, Van Staden CJ (2011) The effect of board characteristics on firm environmental performance. J Manag 37(6):1636-1663

Demirgüç-Kunt A, Maksimovic V (1999) Institutions, financial markets, and firms' choice of debt maturity. The World Bank, Wasington 
Devos E, Rahman S, Tsang D (2017) Debt covenants and the speed of capital structure adjustment. J Corp Finan 45:1-18

Dore R (2005) Deviant or different? Corporate governance in Japan and Germany. Corp Govern Int Rev 13(3):437-446

Drobetz W, Wanzenried G (2006) What determines the speed of adjustment to the target capital structure? Appl Financ Econom 16(13):941-958

Edwards J, Nibler M (2000) Corporate governance in Germany: the role of banks and ownership concentration. Econom Policy 15(31):238-267

Elsas R, Florysiak D (2011) Heterogeneity in the speed of adjustment toward target leverage. Int Rev Financ 11(2):181-211

Endo K (2020) Corporate governance beyond the shareholder-stakeholder dichotomy: Lessons from Japanese corporations' environmental performance. Bus Strateg Environ 29(4):1625-1633

Faccio M, Marchica M-T, Mura R (2016) CEO gender, corporate risk-taking, and the efficiency of capital allocation. J Corp Finan 39:193-209

Faulkender M, Flannery MJ, Hankins KW, Smith JM (2012) Cash flows and leverage adjustments. J Financ Econ 103(3):632-646

Fauver L, Fuerst ME (2006) Does good corporate governance include employee representation? Evidence from German corporate boards. J Financ Econ 82(3):673-710

Feils D, Rahman M, Şabac F (2018) Corporate governance systems diversity: a coasian perspective on stakeholder rights. J Bus Ethics 150(2):451-466

Ferreira D, Ferreira MA, Mariano B (2018) Creditor control rights and board independence. J Financ 73(5):2385-2423

Frank MZ, Goyal VK (2003) Testing the pecking order theory of capital structure. J Financ Econ 67(2):217-248

Frank MZ, Goyal VK (2009) Capital structure decisions: which factors are reliably important? Financ Manage 38(1):1-37

Franks J, Mayer C (1998) Bank control, takeovers and corporate governance in Germany. J Bank Finance 22(10-11):1385-1403

Frye MB, Pham DT (2018) CEO gender and corporate board structures. Q Rev Econ Finance 69:110-124. https://doi.org/10.1016/j.qref.2017.12.002

Graham JR, Leary MT (2011) A review of empirical capital structure research and directions for the future. Annu Rev Financ Econ 3(1):309-345

Gul FA, Srinidhi B, Ng AC (2011) Does board gender diversity improve the informativeness of stock prices? J Account Econ 51(3):314-338. https://doi.org/10.1016/j.jacceco.2011.01.005

Hackbarth D (2008) Managerial traits and capital structure decisions. J Financial Quant Anal 43(4):843-881

Hahn PD, Lasfer M (2016) Impact of foreign directors on board meeting frequency. Int Rev Financ Anal 46:295-308

Hansen, L. P. (1982). Large sample properties of generalized method of moments estimators. Econometrica: Journal of the Econometric Society, 1029-1054.

Harris M, Raviv A (1991) The theory of capital structure. J Financ 46(1):297-355

Harvey CR, Lins KV, Roper AH (2004) The effect of capital structure when expected agency costs are extreme. J Financ Econ 74(1):3-30

Hermalin BE, Weisbach MS (1988) The determinants of board composition. RAND J Econom 19:589-606

Himmelberg CP, Tsyplakov S (2020) Optimal terms of contingent capital, incentive effects, and capital structure dynamics. J Corp Financ 64:101635

Hopt KJ, Leyens PC (2004) Board models in Europe-recent developments of internal corporate governance structures in Germany, the United Kingdom, France, and Italy. Eur Company Financ Law Rev 1(2):135-168

Hovakimian A, Opler T, Titman S (2001) The debt-equity choice. J Financ Quant Anal 36:1-24

Huang R, Ritter JR (2009) Testing theories of capital structure and estimating the speed of adjustment. J Financ Quant Anal 44:237-271

Jackson G, Moerke A (2005) Continuity and change in corporate governance: Comparing Germany and Japan. Corporate Govern Inter Rev 13(3):351-361

Jensen MC (1993) The modern industrial revolution, exit, and the failure of internal control systems. J Financ 48(3):831-880

Jensen MC, Meckling WH (1976) Theory of the firm: Managerial behavior, agency costs and ownership structure. J Financ Econ 3(4):305-360

Ji J, Talavera O, Yin S (2020) Frequencies of board meetings on various topics and corporate governance: evidence from China. Rev Quant Financ Acc 54(1):69-110 
Johnson RA, Schnatterly K, Johnson SG, Chiu SC (2010) Institutional investors and institutional environment: A comparative analysis and review. J Manage Stud 47(8):1590-1613

Kao EH, Huang H-C, Fung H-G, Liu X (2020) Co-opted directors, gender diversity, and crash risk: evidence from China. Rev Quant Financ Acc 55(2):461-500

Kieschnick R, Moussawi R (2018) Firm age, corporate governance, and capital structure choices. J Corp Finan 48:597-614

Kim KA, Kitsabunnarat-Chatjuthamard P, Nofsinger JR (2007) Large shareholders, board independence, and minority shareholder rights: Evidence from Europe. J Corp Finan 13(5):859-880

Köke J (2004) The market for corporate control in a bank-based economy: a governance device? J Corp Finan 10(1):53-80

Komal B, Ezeani E, Shahzad A, Usman M, Sun J (2021) Age diversity of audit committee financial experts, ownership structure and earnings management: evidence from China. Inter J Financ Econom. https:// doi.org/10.1002/ijfe. 2556

Komera S, Lukose. (2016) Heterogeneity and asymmetry in speed of leverage adjustment: The Indian experience. Rev Pac Basin Financ Mark Policies 19(03):1650019

La Porta R, Lopez-de-Silanes F, Shleifer A, Vishny R (2000) Investor protection and corporate governance. J Financ Econ 58(1-2):3-27

Leary MT, Roberts MR (2005) Do firms rebalance their capital structures? J Financ 60(6):2575-2619

Leland HE, Toft KB (1996) Optimal capital structure, endogenous bankruptcy, and the term structure of credit spreads. J Financ 51(3):987-1019

Levine R (2002) Bank-based or market-based financial systems: which is better? Journal of Financial Intermediation 11(4):398-428

Liao LK, Mukherjee T, Wang W (2015) Corporate governance and capital structure dynamics: an empirical study. Journal of Financial Research 38(2):169-192

Linck JS, Netter JM, Yang T (2008) The determinants of board structure. J Financ Econ 87(2):308-328

Lipson ML, Mortal S (2009) Liquidity and capital structure. J Financ Markets 12(4):611-644

Lorca C, Sánchez-Ballesta JP, García-Meca E (2011) Board Effectiveness and Cost of Debt. J Bus Ethics 100(4):613-631. https://doi.org/10.1007/s10551-010-0699-3

Mauer DC, Sarkar S (2005) Real options, agency conflicts, and optimal capital structure. J Bank Finance 29(6): 1405-1428

Mills GT (1996) The impact of inflation on capital budgeting and working capital. J Financ Strateg Decis 9(1):79-87

Miwa Y, Ramseyer JM (2005) Who appoints them, what do they do? Evidence on outside directors from Japan. J Econom Manag Strat 14(2):299-337

Morellec E, Nikolov B, Schürhoff N (2012) Corporate governance and capital structure dynamics. J Financ 67(3):803-848

Nguyen NH, Phan HV, Lee E (2020) Shareholder litigation rights and capital structure decisions. J Corporate Financ 62:101601

O’Sullivan M (2003) The political economy of comparative corporate governance. Rev Inter Political Econom 10(1):23-72

Ozkan A (2001) Determinants of capital structure and adjustment to long run target: evidence from UK company panel data. J Bus Financ Acc 28(1-2):175-198

Öztekin Ö (2015) Capital structure decisions around the world: which factors are reliably important? J Financ Quant Anal 50(3):301-323

Öztekin Ö, Flannery MJ (2012) Institutional determinants of capital structure adjustment speeds. J Financ Econ 103(1):88-112

Palvia A, Vähämaa E, Vähämaa S (2015) Are female ceos and chairwomen more conservative and risk averse? Evidence from the banking industry during the financial crisis. J Bus Ethics 131(3):577594. https://doi.org/10.1007/s10551-014-2288-3

Platt H, Platt M (2012) Corporate board attributes and bankruptcy. J Bus Res 65(8):1139-1143

Rajan RG, Zingales L (1995) What do we know about capital structure? Some evidence from international data. J Financ 50(5):1421-1460

Rampini AA, Viswanathan S (2013) Collateral and capital structure. J Financ Econ 109(2):466-492

Reguera-Alvarado N, de Fuentes P, Laffarga J (2017) Does board gender diversity influence financial performance? Evidence from Spain. J Bus Ethics 141(2):337-350. https://doi.org/10.1007/ s10551-015-2735-9

Robinson G, Dechant K (1997) Building a business case for diversity. Acad Manag Perspect 11(3):21-31

Schmidt RH, Tyrell M (1997) Financial systems, corporate finance and corporate governance. Eur Financ Manag 3(3):333-361 
Shyam-Sunder L, Myers SC (1999) Testing static tradeoff against pecking order models of capital structure. J Financ Econ 51(2):219-244

Titman S, Wessels R (1988) The determinants of capital structure choice. J Financ 43(1):1-19

Tran DH (2014) Multiple corporate governance attributes and the cost of capital-evidence from Germany. Br Account Rev 46(2):179-197

Upadhyay AD, Bhargava R, Faircloth SD (2014) Board structure and role of monitoring committees. J Bus Res 67(7):1486-1492

Uribe-Bohorquez M-V, Martínez-Ferrero J, García-Sánchez I-M (2018) Board independence and firm performance: The moderating effect of institutional context. J Bus Res 88:28-43

Vafeas N (1999) Board meeting frequency and firm performance. J Financ Econ 53(1):113-142

Viénot M (1999) Report of the AFEP-MEDEF Committee on corporate governance. In: Paris.

Wang C-J (2012) Board size and firm risk-taking. Rev Quant Financ Acc 38(4):519-542

Wanzenried G (2006) Capital structure dynamics in the UK and continental Europe. Eur J Financ 12(8):693-716

Witt MA, Redding G (2012) The spirits of corporate social responsibility: Senior executive perceptions of the role of the firm in society in Germany, Hong Kong, Japan, South Korea and the USA. Soc Econ Rev 10(1):109-134

Yermack D (1996) Higher market valuation of companies with a small board of directors. J Financ Econ 40(2):185-211

Zhou Q, Tan KJK, Faff R, Zhu Y (2016) Deviation from target capital structure, cost of equity and speed of adjustment. J Corp Finan 39:99-120

Publisher's Note Springer Nature remains neutral with regard to jurisdictional claims in published maps and institutional affiliations. 